\title{
Financial Deepening, Venture Capital and Economic Growth in China
}

\author{
Lifeng $\mathrm{Tu}^{*}$, Guiming Qiao \\ Dongwu Business School (Finance and Economics School), Soochow University, China \\ *Corresponding author: Lifeng Tu, associate professor, PHD candidate, lifengtu@126.com
}

\begin{abstract}
We construct panel data sets for 31 provinces in China, covering the period 2001 2015, and to estimate empirical equations to investigate the impact of financial deepening on local economic growth. The results underline the important role played by different financial sectors in promoting economic development. A robust finding is that banking system, appear to be statistically and quantitatively more significant than nonbank financial markets and venture capital investment. This is consistent with the fact that banking system is the first choice as financial service in China. We also conclude that well developed venture capital industry accelerates the pace of innovative economic development in China.
\end{abstract}

Key words: financial deepening; venture capital; economic growth; banking system; nonbank financial markets

\section{Introduction}

The relationship between the financial deepening and economic development has been receiving considerable attention in the literature. The findings broadly argue that financial sector enable individuals to shift expenditure from the present into the future so as to acquire more returns. Financial sector could be categorized into three institutions, i.e., banking system, the nonbank financial markets and the private equity market. Banking system aid investment and economic growth by mobilizing savings. They provide lenders financial instruments of low risk but high quality, and buy the liabilities of borrowers at lower liquidity and yield, but a larger principal. Due to the existence of asymmetric information, banks bear information and transaction costs, consequently, they reduce the ensuing inefficiencies by acquiring information on the quality of individual loans. A liquid nonbank financial markets, such as stock market, bond market and fund market, facilitate investment since they enable investors to cheaply and efficiently trade ownership of claims. Venture capital investment, as typical private equity, is one of the most effective ways to finance newly established innovative companies, which hardly have access to other types of external financial resource. It is argued that venture capital is an active financial intermediary, which is in sharp contrast with most financial intermediaries such as banks or stock market investors that assume a passive role. Once the latter invest in a company, they may pay attention to the financial performance of the company periodically but seldom involve in the decision making. In order to mitigate the huge business and financial risks and the potential agency problems associated with investing in growth oriented companies, venture capital firms specialize in selecting the most promising ones and in being supervised in them.

A study on the impact of financial deepening on economic growth in China is motivated by a variety of reasons. Since 2003, China's economic strength has been rapidly enhanced. China's 
central authority has actively implemented policies of market-based institutional reform, which have been expected to positively influence both economic growth and financial resources (Busenitz and Lau, 2001¹). However, China's financial sector is still dominated by a small number of major state-owned banks. China’s Big Four banks, Bank of China, China Construction Bank, the Industrial and Commercial Bank of China, and Agricultural Bank of China, have far more market power over the financial industry than do the thousands of other financial institutions. Other banks, include joint-stock commercial banks, credit cooperatives, and urban commercial banks, comprise a little over half of lending activity in China. An important development of China's financial sector is its stock market growth since 1991, which is the second largest in the world by equity value but is dominated by state-owned firms. In order to foster a stock market that can compete with those of developed countries, the Chinese Government is committed to apply a serious of reforms, such as the refinement of the legal system governing the capital market. The bond market includes government and corporate bonds. Government bonds are most actively traded, but are purchased by stateowned banks. Corporate bonds incur large transaction costs during the issuance process and have been insufficiently rated by China's ratings agencies, leading to potential defaults of companies whose debt quality was overestimated. China has been the second largest venture capital market in the world since 2001. Venture capital investment plays an important role in the start-up of innovative companies in China. Guo and Jiang $(2013)^{2}$ reports that over have of venture capital investment in China are in the high-tech industries.

Despite the widespread interest in financial service as a stimulus for economic growth, however, there is little literature on the potential impacts of China's financial deepening on GDP and potential GDP. The present paper is one of the attempts to investigate the nexus between financial sector and regional economic development, making joint use of banking system indicators, nonbank financial markets and venture capital values obtained in a provincial context. The aim of this paper is to empirically analyse the causal association and long-term relationship between financial deepening and economic growth in China, within a panel data framework.

The paper is structured as follows. Section 2 briefly reviews the literature on the nexus between finance and economic development. Section 3 presents the econometric methodology and the data used. Section 4 describes the results and discusses the robustness. Finally, Section 5 concludes.

\section{Literature Review}

Study of the nexus between finance and economic growth started from the works of Schumpeter (1911), who underlined the boost to production and growth supported by a welldeveloped financial sector. According to the theory of Pagano $(1993)^{3}$, the development of the financial sector promotes real growth, since it provides a means of overcoming market frictions and raises the productivity of capital, and it may reduce the cost of financial intermediation.

Recently, written about the relationship between finance and economic growth has generated a large body of empirical evidences which show, with a few exceptions, a positive causal relationship between financial and economic growth. In terms of methodology, the main tool used is the growth regression, where a combination of financial variables associated with a 
large sample of countries/regions, conjoined with several additional control variables, are used to explain economic growth. Zaman et al. (2010) ${ }^{4}$ find co-integrated relationship between economic growth, trade openness and financial development in both the long-term and short-term. Darrat (1999) ${ }^{5}$ provides evidence that financial deepening is a causal factor in economic growth. Nieuwerbugh et al. (2005) ${ }^{6}$ find strong proof indicating that stock market development induces economic growth. Tharavaniji (2007) ${ }^{7}$ finds that countries with wellfunctioned capital markets are faced with less contraction in their business cycles and consequently less susceptible to economic downturns. Aziz and Duenwald (2002) ${ }^{8}$ provide the evidence that financial development is an important influence factor on growth through private savings, investment liberalization in China.

Finally, mention must be made of the lack of studies on segments of the financial industry apart from banking system and the security market. Of the few which have appeared, some of them focus on the role of bond market development in promoting economic growth (Turner, 2003) ${ }^{9}$ while other studies have explicitly introduced the role of venture capital investments. The macro level nexus between the supply of venture capital and economic growth has been the subject of little empirical studies, and some questions are still unanswered.

The brief review of the literature presented above suggests the following hypotheses to be tested in the remainder of the paper:

$\mathrm{H} 1$ the greater the level of the development of banking system-proxied by the ratio of deposit or loan to GDP, the higher the rate of economic growth.

$\mathrm{H} 2$ the greater the level of the development of nonbank financial markets-proxied by the ratio of stock, bond or fund to GDP, the higher the rate of economic growth.

$\mathrm{H} 3$ the higher the level of the development of private equity market-proxied by the ratio of venture capital investments to GDP, the higher the rate of economic growth.

\section{Methodology and Data}

Due to our dataset contains 31 provinces of China for the period of 2001 to 2015, it is feasible to use short panel data method. At first, let $y_{i, t}$ be the natural logarithm of per capita GDP in province $\mathrm{i}$ at time $\mathrm{t}$, then, we take GDP index(1978=100) as $y_{i, t}$. We want to regress the following equation:

$y_{i, t}=\alpha_{0}+\alpha_{1}$ DEPOSIT $_{i, t}+\alpha_{2}$ LOAN $_{i, t}+\alpha_{3} V C_{i, t}+\alpha_{4}$ STOCK $_{i, t}+\alpha_{5}$ FUND $_{i, t}+$

$\alpha_{6} B O N D_{i, t}+\eta_{i}+\varepsilon_{i, t}$

We introduce a set of explanatory variables, including total deposit, total loan, venture capital investment, money raised from stock market, fund market and bond market. All these financial variables are divided by GDP and in natural logarithm to capture possible nonlinearity in the relationship between financial development and economic growth. $\eta_{i}$ captures the unobserved province-specific effect and $\varepsilon_{i, t}$ is an error term. We also include in our regressions some control variables and take them as proxies for innovation: $R \& D$ expenditure, patent applications and granted patents. Rewriting the previous question as:

$y_{i, t}=\alpha_{0}+\alpha_{1}$ DEPOSIT $_{i, t}+\alpha_{2}$ LOAN $_{i, t}+\alpha_{3} V C_{i, t}+\alpha_{4}$ STOCK $_{i, t}+\alpha_{5}$ FUND $_{i, t}+$ $\alpha_{6}$ BOND $_{i, t}+\beta_{1} R \& D E X P_{i, t}+\beta_{2} P A P P_{i, t}+\beta_{3} P G R A N T_{i, t}+\eta_{i}+\varepsilon_{i, t}$ 
The data on provincial economic activity were obtained from the website of National Bureau of Statistics of the People's Republic of China. All financial data and innovation data are selected from the financial dataset of WIND info.

Table 1 provides the summary statistics of 31 provinces, including means, minimums, maximums, and standard deviations of per capita GDP, GDP index, all financial variables and innovation proxies.

Table 1-Descriptive statistics

\begin{tabular}{|l|l|c|l|l|l|l|}
\hline Variable & \multicolumn{1}{|c|}{ Definition } & Obs & \multicolumn{1}{|c|}{ Mean } & Std.Dev. & Min & Max \\
\hline GDPK & natural logarithm of per capita GDP & 465 & 9.967 & 0.776 & 8.006 & 11.59 \\
\hline GDPI & GDP index(1978=100) & 465 & 7.606 & 0.591 & 6.252 & 8.999 \\
\hline DEPOSIT & $\begin{array}{l}\text { natural logarithm of the ratio of deposit to } \\
\text { GDP }\end{array}$ & 401 & 0.406 & 0.335 & -0.286 & 1.722 \\
\hline LOAN & $\begin{array}{l}\text { natural logarithm of the ratio of credit to } \\
\text { GDP }\end{array}$ & 403 & 0.0655 & 0.323 & -0.621 & 0.950 \\
\hline VC & $\begin{array}{l}\text { natural logarithm of the ratio of venture } \\
\text { capital investment to GDP }\end{array}$ & 376 & -7.398 & 1.753 & -12.97 & -2.459 \\
\hline STOCK & $\begin{array}{l}\text { natural logarithm of the ratio of money } \\
\text { raised from stock market to GDP }\end{array}$ & 465 & -0.282 & 1.102 & -3.674 & 3.443 \\
\hline FUND & $\begin{array}{l}\text { natural logarithm of the ratio of money } \\
\text { raised from fund market to GDP }\end{array}$ & 465 & -4.501 & 1.532 & -9.276 & 0.698 \\
\hline BOND & $\begin{array}{l}\text { natural logarithm of the ratio of money } \\
\text { raised by issuing bond to GDP }\end{array}$ & 464 & -2.112 & 2.319 & -14.61 & 3.424 \\
\hline R\&DEXP & $\begin{array}{l}\text { natural logarithm of the ratio of expenditure } \\
\text { on R\&D to GDP }\end{array}$ & 420 & -5.590 & 1.194 & -9.846 & -1.917 \\
\hline PAPP & $\begin{array}{l}\text { natural logarithm of amount of patent } \\
\text { applications }\end{array}$ & 434 & 8.995 & 1.773 & 2.708 & 13.13 \\
\hline PGRANT & $\begin{array}{l}\text { natural logarithm of amount of patent } \\
\text { granted }\end{array}$ & 434 & 8.375 & 1.762 & 1.946 & 12.51 \\
\hline
\end{tabular}

\section{Empirical Results and Discussion}

Hausman (1978) proposed a test based on the difference between the random effects(RE)and fixed effects estimates(FE). The test of over-identifying restrictions provides the SarganHansen statistic of 33.682, and the P-value of 0 . Hence, we choose FE model for our specification, whose results are presented in table 2 . The model(1) and model(2) take GDPK as dependent variable, and the model(3) and model(4) take GDPI as dependent variable, since these serve as different proxies for economic growth. For robust check, we also include three variables as proxies for provincial innovation input and output in model(2) and model(4). The explanatory power of all these models is high, with $\mathrm{R}^{2} \mathrm{~s}$ ranging from 0.674 to 0.926 .

The findings from table 2 indicate important role played by financial deepening in economic growth. The coefficients related to LOAN are always negative and significant, the coefficients related to VC, STOCK and BOND are positive and significant. The coefficients related to DEPOSIT are only positive and significant in model(1) and model(3), which means that the results for DEPOSIT are not robust when we take innovation factors into consideration.

According to model(1), the marginal effect for DEPOSIT on GDPK is 1.3433, which means that a $1 \%$ increase in DEPOSIT is associated with a $1.3433 \%$ increase in GDPK. Similarly, a $1 \%$ increase in LOAN is associated with a $0.9049 \%$ decrease in GDPK, a $1 \%$ increase in VC, 
STOCK or BOND respectively corresponds to a $0.0773 \%$, a $0.2349 \%$ or a $0.1596 \%$ increase in GDPK. When we consider some innovation proxies in model(2), the conclusions are generally robust, only marginal effects of LOAN, VC, STOCK and BOND become smaller than those in model(1).

In model(3), there is evidence that a $1 \%$ increase in DEPOSIT implies a $1.1485 \%$ increase in GDPI, but this result is not significant in model(4). In model(3), a $1 \%$ increase in LOAN is associated with a $0.6208 \%$ decrease in GDPI, a $1 \%$ increase in VC, STOCK or BOND imply respectively a $0.0597 \%$, a $0.1726 \%$ or a $0.12 \%$ increase in GDPI. The conclusions are robust in model(4), only marginal effects become smaller than those in model(3). The marginal effect in model(3) indicates that a $1 \%$ increase in FUND corresponds to a $0.0544 \%$ increase in GDPI, but this result is not significant in model(4).

Table 2- Fixed effects panel regression

\begin{tabular}{|l|c|c|c|c|}
\hline Variables & $(1)$ GDPK & $(2)$ GDPK & $(3)$ GDPI & $(4)$ GDPI \\
\hline \multirow{2}{*}{ DEPOSIT } & $1.3433^{* *}$ & 0.0203 & $1.1485^{* * *}$ & 0.1538 \\
& $(0.5791)$ & $(0.3019)$ & $(0.4039)$ & $(0.2757)$ \\
\hline \multirow{2}{*}{ LOAN } & $-0.9049^{* *}$ & $-0.5996^{* *}$ & $-0.6208^{*}$ & $-0.3978^{*}$ \\
& $(0.4265)$ & $(0.2230)$ & $(0.3049)$ & $(0.2005)$ \\
\hline \multirow{2}{*}{ VC } & $0.0773^{* * *}$ & $0.0205^{* *}$ & $0.0597^{* * *}$ & $0.0161^{* *}$ \\
& $(0.0148)$ & $(0.0087)$ & $(0.0112)$ & $(0.0067)$ \\
\hline \multirow{2}{*}{ STOCK } & $0.2349^{* * *}$ & $0.0839^{* * *}$ & $0.1726^{* * *}$ & $0.0522^{* *}$ \\
& $(0.0471)$ & $(0.0262)$ & $(0.0358)$ & $(0.0210)$ \\
\hline \multirow{2}{*}{ FUND } & 0.0380 & -0.0234 & $0.0544^{* *}$ & 0.0114 \\
& $(0.0286)$ & $(0.0202)$ & $(0.0222)$ & $(0.0159)$ \\
\hline \multirow{2}{*}{ BOND } & $0.1596^{* * *}$ & $0.0471^{* *}$ & $0.1200^{* * *}$ & $0.0341^{* *}$ \\
& $(0.0249)$ & $(0.0183)$ & $(0.0185)$ & $(0.0164)$ \\
\hline \multirow{2}{*}{ R\&DEXP } & & $-0.0495^{*}$ & & $-0.0406^{*}$ \\
& & $(0.0282)$ & & $(0.0200)$ \\
\hline \multirow{2}{*}{ PAPP } & & $0.2793^{* * *}$ & & $0.1654^{* * *}$ \\
& & $(0.0581)$ & & $(0.0473)$ \\
\hline \multirow{2}{*}{ PGRANT } & $90.87^{* * *}$ & $107.03^{* * *}$ & $119.39^{* * *}$ & $149.05^{* * *}$ \\
\hline \multirow{2}{*}{ Constant } & 0.674 & 0.926 & 0.712 & 0.927 \\
\hline Year dummies & controlled & controlled & controlled & controlled \\
\hline Province dummies & controlled & controlled & controlled & controlled \\
\hline Observations & $10.7496^{* * *}$ & $4.8453^{* * *}$ & $8.2560^{* * *}$ & $3.7839^{* * *}$ \\
\hline F & $(0.2567)$ & $(0.4812)$ & $(0.2075)$ & $(0.3962)$ \\
\hline$R^{2}$ & & 342 & & 313 \\
\hline
\end{tabular}

Standard errors in parentheses; ${ }^{*} p<0.1,{ }^{* *} p<0.05,{ }^{* * *} p<0.01$

As one would expect, the degree of provincial economic growth increases steadily as the level of financial deepening improves longer. This is consistent with most academic financial deepening research. Among all financial variables, the marginal effect of DEPOSIT is greatest, which indicates that people are more likely to use banks. For enterprises or investors, the stock market is the second main choice, followed by the bond market. We also could conclude that the role of venture capital becomes more and more important in supporting economic development. To conclude, we find that the greater the level of the development of 
banking system(H1), or nonbank financial markets(H2), or private equity market(H3), the higher the rate of economic growth. These results are shown to be robust for the inclusion of innovation proxy variables.

\section{Conclusions}

This article investigates some factors rarely discussed in the literature on finance and growth: financial intermediaries' capacity for local economic growth, especially, venture capital investment, seen as a catalyst for innovation and entrepreneurship. Besides the evidence for the role of banking system, security market and bond market play in promoting economic development, we find the significant proof that the more development of local venture capital investment, the higher level of economic growth.

This paper finds that the greater the level of financial deepening the higher the rate of local economic growth. Moreover, the distinction between banking system, nonbank financial markets as well as private equity market suggests that all types of financial organizations are imperative for regional growth, but the role of banks is greater, while venture capital are more important in high innovation activities, and the conclusion is sound and stable over time.

\section{Acknowledgements}

We gratefully acknowledge funding from the educational department of Jiangsu Province, China, the Philosophy \& Social Science Research Foundation of the Higher Education Institutions of Jiangsu Province(2014SJB531), and data from the Wind Info.

\section{References}

1. L.W. Busenitz, C.M. Lau, Growth intentions of entrepreneurs in a transitional economy: The People's Republic of China. Entrepreneurship: Theory and Practice 26.1 (2001)521.

2. D. Guo, K. Jiang,Venture capital investment and the performance of entrepreneurial firms: Evidence from China. Journal of Corporate Finance 22 (2013)375-395.

3. Pagano, Marco. Financial markets and growth: an overview. European economic review 37.2-3 (1993)613-622.

4. K. Zaman, Trade Liberalization, Financial Development and Economic Growth: Evidence from Pakistan (1980-2009). Journal of International Academic Research 10.2 (2010).

5. F. A. Darrat, Are financial deepening and economic growth causally related? Another look at the evidence. International Economic Journal 13.3 (1999)19-35.

6. V. Nieuwerburgh, Stijn, F. Buelens, and L. Cuyvers, Stock market development and economic growth in Belgium. Explorations in Economic History 43.1 (2006)13-38.

7. P.Tharavanij, Capital Market, Severity of Business Cycle, and Probability of an Economic Downturn. Monash University Economics Discussion Paper (2007).

8. J. Aziz, C. Duenwald, Growth-financial intermediation nexus in China. No. 2002-2194. International Monetary Fund, 2002.

9. P.Turner, Bond market development: what are the policy issues?. a joint World Bank/IMF/Brookings Institution conference on the Future of Domestic Capital Markets in Developing Countries, April. 2003. 